\title{
The Dolalak Dance of Purworejo Regency Central Java: A Changing Performance as Entertainment
}

\author{
Riva Amelia, R.M. Pramutomo, Indonesia Institute of the Arts Surakarta, \\ University of Limerick, Ireland, Email: rivaamelia2207@gmail.com, \\ rmpram60@gmail.com
}

\begin{abstract}
Dolalak dance is a type of folk dance originating from Purworejo Regency, Central Java Province. Research on Dolalak Dance has been carried out by many dance researcher's with various perspectives. However, Dolalak Dance in Central Java still has its appeal and uniqueness to be studied with new perspectives. This article is a new perspective on Dolalak Dance which sees changes in appearance due to the presence of the women's Dolalak dance group. The perspective used in this article is ethnocoreology. This is an interdisciplinary study that focuses on the changing aspects of the origins of the Dolalak dance with religious nuances and then turn it into an entertainment and performance art, with a new style of appearance. The ethnocoreological approach views dance as a cultural product. In such a sense, ethnochoreological analysis is based on the ethnographic method of dance from the physical point of view of the Dolalak dance performers and all aspects of its appearance. Thus, this article is a way of looking at Dolalak dance from the point of view of changing the aesthetic response of the female Dolalak dancers to become a model of entertainment performance art.
\end{abstract}

Key words: Dolalak dance, performance elements, female dancing bodies, style, and ethnochoreology

\section{Introduction}

Information about the Dolalak dance is mostly obtained from the oral tradition. Information compiled by Th. Pigeaud in the book Javaanse Volksvertoningen in 1935 only mentions a form of group dance marching and dressed as Dutch soldiers (Pigeaud; 1935: 121--123). This image was most likely known at that time as the Dolalak dance. Nanik Sri Prihatini's (2003) provides an overview of Dolalak dance as a folk dance performance art or commonly known as 
folksdance (Prihatini; 2003: 14--15). The history of the creation of the Dolalak dance itself is an oral tradition associated with Dutch colonial soldiers who were previously stationed in the Bagelen Residency. This area is now known as Purworejo Regency. Through the oral tradition, the Dutch colonial soldiers connected with the Dolalak dance were very close to the sound of the Do-La-La tone, which was usually used as a dance accompaniment for Dutch colonial soldiers at that time. For this reason, the basis for the imitation of this musical tone is pronounced according to the Javanese as dolalak, as it is known today.

In the beginning, Dolalak dancingwas not accompanied by musical instruments. Musical elements that are used as Javanese imitations are performed by singing certain poems used as Dolalak dance music. In turn, the development of the elements of Dolalak dance music is equipped with jidur, fly, kecer, and drums. Songs or poems used by rhymes can contain guidance or advice. The language in poetry and pantun is a mixed language between Javanese and Indonesian. The most striking thing is the closeness to the influence of the imitation of Dutch Colonial soldiers in the Dolalak dancers' dress. This element is supported by the rank attribute on the long sleeve shirt and the distinctive pet hat that is used as characteristics, including sunglasses.

Salimah submitted another study in 2007 regarding the relationship between the origins of the Dolalak dance and the existence of Dutch colonial soldiers in the Bagelen Residency. His research, states that the 1936 figure was the beginning of the creation of the Dolalak dance. In information compiled by the Purworejo Regency Government in 1997, it is said that the Dolalak dance is a typical type of shalawatan dance. The designation of the distinctive shalawatan dance is an identity that is related to Islamic elements. This is especially directly related to poetry taken in the Barzanji Book which in Javanese Muslims is often associated with the mission of the da'wah in the content of the songs in the verse. However, it was also stated that the background of the creation of the Dolalak dance was very different from the type of shalawatan because of the influence of imitation on the Dutch Colonial soldiers in the visual of the dress.

As in the research conducted by Salimah, several recent studies also show similarities in information. In the results of Salimah's research, it is also known about the relationship between the role of the Dolalak dance and the spread of Islam in the Purworeja Regency area, especially in the Kaligesing area. Several aspects of the role shown from Salimah's research focus on the form of song offerings and lyrics in the Dolalak dance which carry Islamic elements (Salimah; 2007: 24-26). From the conclusion of the results of this research, Dolalak dance originally had the objective of Da'wah or Syi'ar elements in the spread of Islam to the Javanese community. . In Sutrisno (2010) view, the development of the Dolalak dance is similar to what happened in Angguk art. These two art genres do have similarities in terms of appearance. However, the Dolalak dance adopted the tone of the song sung in imitation of the Dutch at that time. (Isbandi; 2010: 334-337). The similarities that occur in the orientation area are caused by the markets 
appetite for changes in appearance and songs that are sung more popularly. Djarot Heru Santosa, Timbul Haryana and R.M. Soedarsono (2013) explain that the position of the Dolalak dance which has been danced by female dancers with all the implications of the changing aspects of Islam (Santosa et.al .; 2013: 227-334). This paper shows the meaning of the role of female dance performers in the Dolalak dance when it is related to the values of da'wah and the spread of Islam in Java.

From some of the research results and relevant sources, Dolalak dance clearly has a unique position in the context of Javanese folk dance performance. The colors of colonialism, elements of marching soldiers, elements of the Barzanji Book, the message of the da'wah in the contents of the book, the attributes and clothing of Colonial soldiers, complete with black glasses give the characteristics and uniqueness of the Dolalak dance. On that basis this article will examine a pattern of endurance of the Dolalak dance from its origin when it changes its presentation form as an art of entertainment.

\section{Method}

This article using ethnocoreology as research approach with a focus on the aspects of changing the Dolalak dance presentation style as a result of female dancing bodies on entertainment dance performances. Several sub-studies from this aspect will be seen through an ethnographical dance research method. Following the opinion of Horton-Freleigh and Heinstein, the excellence of study with the dance ethnographic method because of dance is always seen as a cultural product. For this reason it is explained as follows.

Dance always has style. Style is the 'how' of dancing, its aesthetic character. It arises in the viewer as a matter of perception and interpretation in relation to the dance event. We can think of style in two senses: the embodied characteristics of the dance, and the dancer's individual qualitaties as personal signature (Horton-Freleigh and Heinstein eds. ; 1999: 8).

The excellence factor is shown in dance as a cultural product that always has a "style". In the view of Horton-Freleigh and Heinstein, the contextuality of cultural products tends to have a degree of uniqueness. It seems that this characteristic is a prerequisite for contextual studies in ethnochoreology. Another form of prerequisite can also be explained from understanding the terminological factors in local dance culture. This somewhat closer reference is put forth from Clifford Geertz's thought as follows.

... whatever and whenever symbol systems "in their own terms" may be we gain empirical acces to them by inspecting events not by arranging abstracted entities into unified patterns (Geertz; 1973: 17). 
According to Geertz's thinking, it is stated that the formation of symbolic systems in local dance culture is measured by 'their own terms'. Therefore the meaning obtained from the empirical access of a researcher will depend on the acquisition of meanings in 'terms' that appear in a dance event. This can be illustrated in the example of the completeness of aspects of the performing arts. The completeness includes all elements and substance, both ideographically, visually, and auditively. This is similar to the formation of a symbol system in a choreography (Hawkins; 1988: 96). The ethnocoreology approach is formed from a rationale borrowed from various disciplines, but the proportion of dance studies that is highlighted is very specific. Due to this qualitative nature, this study also relies heavily on qualitative data. To rely on qualitative data, the field study stage is still an important reference in dance ethnography.

The data collection method is also possible through the micro research stage. This is very necessary in order to see sharply, the status of the relationship between the form of creation and the symbolic process that appears in the genres of dance performance presented by the local community. The determination of this phenomenon can also be based on a reason for qualifying the stylisation pattern that occurs in the local area. In addition, through the phenomenon of the Pandemic era, the development of quality that is presented in the genre of dance presentation and other aspects of the performing arts is also observed, including the response to the audience.

\section{Discussion}

This study used a qualitative method with an ethnocoreology approach as a scientific discipline using the Suzanne K Langer concept. This concept views form as a result of a comprehensive unity of a relationship of various interrelated factors, or a way in which all aspects can be arranged (Langer, 1988: 15). According to Santosa, the art communication concept is the process of delivering and receiving ideas that occurs between two sources that have different functions (Santosa, 2011, 48). The two concepts were utilised by the author to describe and analyse the direction of communication built through the Dolalak dance.

The function of the lyrics in the Dolalak dance song is an important factor in reading the changes in the elements of $d a^{\prime} w a h$ (this is a special term from the Islamic mission to believe their religion) into entertainment value. Poetry in the Dolalak dance is an important element in assessing the content of the $d a^{\prime}$ wah mission that is in the Dolalak dance. In addition, the change in dance actors from male dancers to female dancers that has taken place since the 1970s has become an important aspect of the position of the Dolalak dance as entertainment and performance art. In the Dolalak dance, the songs or dance songs contain religious messages (for Islamic broadcasts), social criticism and messages of development. At first, the Dolalak dance was a means of spreading Islamic religion. However, this religious phenomenon has become a means or medium for delivering da'wah messages. 
The phenomenon that goes on to develop into entertainment arts is becoming interesting. Songs accompanying the Dolalak dance are a means of conveying interesting messages for the audience or listeners. Along with technological developments, Dolalak dance, besides being able to be seen or watched through live performances, is also in the form of VCD recordings, which can be easily obtained on the market. The traditional art of Dolalak dance at this time, whether shown through live performances or VCD recordings, prefers songs or Campur Sari (a special terms of mixed traditional music and western instruments) songs which are becoming a trend in society, especially in Java. At a glance, it can be seen that there is a change in orientation in the presentation of the Dolalak dance. Dolalak dance performance can be enjoyed in the verbal aspect (the lyrics in the song) and non-verbal (the beauty of the dance movements). In other words, with the verbal aspect, the audience can enjoy the songs or songs that accompany the dance. The typical Dolalak song lyrics, along with the messages contained therein are as follows.

Song tittle: Pambuko

Pambukaning kidung minongko pambagyo Pambukaning kidung minongko pambagyo Katur sagung para rawuh ingkang minulyo Miwah asung pudyastowo basuki raharjo Miwah asung pudyastowo basuki raharjo Mugi antuk sihing Hyang moho kuwoso Pambukaning kidung minongko pambagyo Pambukaning kidung minongko pambagyo Katur sagung para rawuh ingkang minulyo Miwah asung pudyastowo basuki raharjo Miwah asung pudyastowo basuki raharjo Mugi antuk sihing Hyang moho kuwoso Milo ing wardoyo kumajelu Milo ing wardoyo kumajelu Sung sunggoto subalelo Awit sedyo ing nolo sayekti amung Awit sedyo ing nolo sayekti amung Amemetri kabudayan kang adi luhung Pambukaning kidung minongko pambagyo Pambukaning kidung minongko pambagyo Katur sagung para rawuh ingkang minulyo Miwah asung pudyastowo basuki raharjo Miwah asung pudyastowo basuki raharjo Mugi antuk sihing Hyang moho kuwoso

Samarinda wong manis mana tempatnya Kabar-kabar cari jodohnya Mulai muda wong manis sabar kuatnya. Pambukaning kidung minongko pambagyo

Pambukaning kidung minongko pambagyo Katur sagung para rawuh ingkang minulyo Miwah asung pudyastowo basuki raharjo Miwah asung pudyastowo basuki raharjo Mugi antuk sihing Hyang moho kuwoso Purworejo kota kita yang berirama Purworejo kota kita yang berirama Bersih Indah Rapi Aman serta Makmur Pembangunan lima tahun jangka panjang Pembangunan lima tahun jangka panjang Kota Purworejo yang terkenal seni nDolalaknya. Pambukaning kidung minongko pambagyo Pambukaning kidung minongko pambagyo Katur sagung para rawuh ingkang minulyo Miwah asung pudyastowo basuki raharjo Miwah asung pudyastowo basuki raharjo Mugi antuk sihing Hyang moho kuwoso. 
Translation:

The opening song as a welcome song, the opening song as a welcoming song, for the audience present, with a wish for safety and well-being, with a wish for good luck and well-being, hope for love from God Almighty, the opening song as a welcome song, this song welcome the audience with a wish for safety and well-being, with a wish for safety and well-being, may we always receive the love of God Almighty, because $\mathrm{He}$ is always at ease, because $\mathrm{He}$ is always at ease, surrender we present it with sincere heart intentions, surrender we present it with heart intent sincere sincerity, only for the sake of maintaining a noble culture, the opening song as a welcome song, the opening song as a song for greetings, for the audience present, with a wish for safety and well-being, with a wish for good luck and prosperity, may we get love from God Almighty,

Samarinda, good people, are reportedly looking for a mate from the youth of good people, hopefully you will always be patient.

This song welcomes the audience with a wish for safety and well-being, with a wish for safety and well-being, may we always receive the love of God Almighty, Purworejo is our city with the rhythm of Purworejo, our city with the rhythm of Clean, Beautiful, Neat, Safe and Prosperous. Development of five years long term. Panjang Kota Purworejo is famous for its nDolalak art. The opening song as a song to greet, for the audience present, with a wish for safety and well-being, with a wish for safety and well-being, hope for the love of God Almighty,

The poem of the Pambuko song or opening contains messages and hopes. It includes first, a welcome greeting to all audiences, the hope of always getting prosperity and being loved by God. In the non-verbal aspect, the audience can enjoy the beautiful movements of the dancers. If at first the Dolalak dance used tembang (traditional song) or accompanying songs containing religious and development messages, in today's development it is more oriented towards entertainment messages only. Messages with religious themes, social criticism, and development, have been marginalised, replaced by popular songs, most of which have the theme of love. It is believed that the way of conveying messages using songs or songs is more effective at reaching the audience, because the language is easy to understand and various other interesting elements such as easy to remember by listeners. This article assumes that changes in the verbal message of tembang in Dolalak dance are aimed at following market tastes or trends, in order to gain economic benefits. The change in orientation in the Dolalak dance song is a small part of the socio-cultural change. According to Mahendra (2009), industrialisation is one of the important forces in social and cultural change in Indonesia, whether that occurs through the introduction of production organisational patterns, values, and/or new norms. This change takes place in three phases. First, changes in agricultural culture due to the entry of markets into the lives of rural farming communities, secondly market integration at the national 
level, and third is market expansion that has brought Indonesia into a network of global relations systems. Market influence becomes more significant in encouraging changes in the style of presentation of Dolalak dance. One proof of this assumption is the proliferation of female Dolalak dancers with a number of elements of eroticism that are designed from fashion and accessories as well as clothing attributes in the style of presentation.

\section{Dolalak and Its Dance Form}

\section{Dolalak Traditional}

Traditionally the Dolalak dance can be presented all night between $4-6$ hours. In the presentation, one song can take up to 30 minutes. The presentation of this form is usually done at the time of the response program. In this form of presentation, usually before performing the dance several rituals are carried out and later in the middle of the dance a special song will be sung to summon the spirit which will cause a trance (mendem in Javanese term). This traditional Dolalak has a peculiarity, namely when performing, the musician ( in Javanese terms is called pengrawit) must be face to face with the dancers. This is so that when a trance occurs, dancers who are experiencing a trance can easily come to the musicians to tell their wishes. At the time of the response, those who want to respond to the Dolalak Dance must also provide offerings. The offerings can consist of roasted ingkung (chicken grill) with / young coconut, fragrant oil (must be fragrant oil with the image of a mermaid), kretek (cloves and tobacco) cigarettes, sans cigarettes, white cigarettes, powder, nylon / small glass, nginang (Javanese ingredients), lawe (string), complete tumpeng rice, free-range chicken eggs, bitter coffee, sweet coffee, bitter tea, and sweet tea, Javanese sugar drink given jipang rice, incense, telon flower (purple rose, white rose, red rose), and put it in a tenong (a traditional plate made from bamboo craft).

\section{Dolalak Kitsch}

The short version (or kitsch) of the Dolalak dance is only played for 15 minutes - 25 minutes, or as needed. The presentation of this form of Dolalak Dance is usually done at dance festival events, welcoming government guests or other events that do not have a long duration. In this packaged Dolalak, there are usually several movements and several dance phrases that are packaged into one short performance.

\section{Elements of Visual Choreography in Dolalak Performance}

1. Dolalak dance movement is a warrior movement dominated by clear and dynamic movements, almost like a refined martial arts movement. The "kirig" movement, which is a fast shoulder movement at certain times, is the hallmark of the Dolalak Dance movement. Movement in this art is divided into 4 movements. Here are some basic movements for the body supporting the Dolalak Dance: - Foot movements: tiptoe, ngetol, pencik, leg lift, sempoh (bent legs), jengkeng 
2. Music for this Dolalak Dance was not originally accompanied by musical instruments, but along with the development of this art began to be accompanied by musical instruments. Musical instruments commonly used are jidur, fly, drums, tambourines, and nowadays, organ, and drums are added.

3. The poetry in this Dolalak song is religious, humorous rhymes, and advice. The title of the song is the name of the dance that is performed. Here are some of the Dolalak dance songs: Jalan-jalan (Going for a walk), Pambukaning (opening), Ikan Cucut (baracuda fish). Iddadahu mama (from Barzanji Literature of moslem), Ambil Baju (Take Cloth) and Kembang Melati (jasmine flower).

4. The make-up and dress of the performers in the Dolalak dance are important visual elements. Make up in Dolalak Dance is not a character make up and there is no characterisation. Dancers in this art only use make-up appropriately, namely the male ones to make them look fresh and the female dancers to make them look beautiful. The costumes in this art imitated the form of clothing used by Dutch officers. The following are the costumes commonly used: a shirt with ruffles, rank and motif for the walang (insecta motif), and shorts. In its development the pants used are not always short. The pants can be adjusted according to the dancer, wearing glasses (generally black), and sampur (long scarf). The colours of the costumes used are usually black with yellow socks and red and white motifs for walang, but along with developments, the colours of the costumes began to adjust to personal tastes.

In the previous discussion, it was mentioned that there was an assessment version of the Dolalak Mlaranan dance. At the beginning of its development the Dolalak Mlaranan version was danced by male dancers (1980-1999). However, due to lack of attraction from the audience who could be less sympathetic to this Dolalak dance, male dancers were eventually changed to female dancers. The Mlaranan version of Dolalak was the first to form with female dancers in the Purworejo Regency. Female Dolalak Mlaranan, which is known to the public, is equipped with a keyboard as the accompanying music. For the costumes at the start of Dolalak, long sleeves were black and pants below the knee, but each Dolalak actor had a way to grab the attention of the audience. "To win over the audience, the pants were above the knee and tight. Thus giving rise to the term "sawer" (spontaneous fee from audience) for the Dolalak Mlaranan dance performers, and this was not typical of Mlaranan. But to be honest as a cultural leader as well as a perpetrator I feel concerned". This was revealed by Wardoyo as the cultural leader and actor of the Dolalak dance (interview, 12 October 2019). In the interview with Wardoyo, the changes in the Dolalak dance and musical instruments, and after being danced by female dancer were discussed. "Dolalak dance instruments, which are used for flying, jidur (Arabic drum), kendhang (Javanese drum), drum, are now organ, bass guitar, kendhang jaipong (Sundanese drum), and drums. In addition, the song lyrics were originally taken from the verses of the Barzanji Book (Sholawat in Quran ) but because they were deemed less attractive, they became poetry that attracted the audience, "explained Wardoyo (interview, 12 October 2019). 
This was reinforced by Untari as Pamong Budaya and Dolalak Dance Trainer, "Apart from what Wardoyo said, the songs used to accompany the Dolalak Dance were songs that were new trends in society" (Interview 12 October 2019).

Dolalak Mlaranan is popular with the community so that people are interested and learn in the Mlaranan group. Many other groups studied in Mlaran such as groups from Pituruh Village, Kemiri Village, Ngombol villages, and they developed their own presentation styles in the Gebang Village and Kutuarjo areas. In addition, Dolalak dance also has the art of entertainment in the presence of a trance or trance. By wearing sunglasses and asking strange requests such as asking to eat jasmine flowers, eating glass like a Kuda Lumping dance (horse dance of Central Java) too. But in the past, the Dolalak dance with a trance was done so that the traditional Dolalak dance could bring a magical element to each of its performances. " currently Dolalak with trance seems to be made up of calling a genie and sometimes some people pretend to be in a trance", explained Wardoyo (interview, 12 October 2019).

\section{Dolalak Female Dancers and Hidden Eroticism on Performance}

Theoretically, the view of performing arts contains several main elements which are the prerequisites for the presentation style. This certainly becomes so strong when the performing arts come from collective, local, and communal cultural roots. Local culture is the cultural characteristic of a local community group. This is what Geertz talks about a lot in cultural interpretation. Geertz's view follows the thoughts of Lehman, Himstreet, and Batty, that culture is defined as a collection of life experiences that exist in their own society. The life experiences of the community are many and varied, including the behaviour and beliefs or beliefs of the community itself (Geertz; 1973; 10). It differs a little with limitations that resemble general views. It is stated that, culture is defined as a collective programming of thoughts that distinguishes the members of one category of people from other categories. In this case, it can also be said that culture is a collective programming that describes a process that binds everyone as soon as they are born.

Geertz (1973) refers to another view that comes from Bovee and Thill who see culture as a shared system of symbols, beliefs, attitudes, values, expectations, and norms for behaviour $(1973 ; 11)$. According to Murphy and Hildebrandt, culture is defined as a typical characteristic of behaviour in a group. This understanding also indicates that verbal and non-verbal communication in a group is also typical of that group and tends to be unique or different from others $(1973 ; 11)$. A view from Mitchel defines culture as a set of core values, beliefs, standards, knowledge, legal morals, and behaviour conveyed by individuals and society, which determine how a person acts, feels, and sees themself and others (Geertz; 1973: 1-12). In terms of the position of the Dolalak dance as a product of local cultural arts and its communal nature, collectively there are indicators of aesthetic behaviour as a form of response from the owner of the art. For this reason, the aesthetic response becomes actionably behavioural. This section is directly related to the process of forming a symbol system in humans. In particular, Morris's behaviour theory contains aesthetic behaviour (Morris: 1977; 34). In the meaning of aesthetic 
behavior, a general definition of art forms is described, namely performance art and plastic art. For the sake of comparison, this may be accompanied by Marvin E Olsen's conception of symbolic interaction and behaviour interaction (Olsen: 1993; 23--28). These two references to the nature of Olsen's interaction are factors that complement Morris's analysis model for the study of performance styles and genres of local ethnic dance culture choreography.

In the realm of this study, an example of a dance study with a specific approach to the Javanese region and the various genres and term traditions inherent in it can be an important contribution to the ethnocoreological approach in Indonesia. This is also due to the added value of ethnocoreology in the analysis system and the comparison method. Of course, the real picture of the analysis system with the comparison method is very visible as a presentation pattern.

Susanti (2006) describes the presentation pattern in the female Dolalak dance. It is stated that Dolalak is one of the folk arts which has its own characteristics and style in every appearance. As folk art, Dolalak contains characteristics namely: it has a social function, is presented together with simple, spontaneous, non-acting movements, the rhythm is light, and contains a magical value, namely that at the peak of the performance a trance occurs. Dolalak is usually performed for four to six hours. The offerings of each type of dance are distinguished by differences in the lyrics of the songs sung, with a total of twenty to sixty songs and each song change stops for a moment so that there is a pause for each variety of motion.

The offerings of each type of dance are distinguished by differences in the lyrics of the songs sung with a total of twenty to sixty songs and each song change stops for a moment so that there is a pause for each variety of motion. Several Dolalak groups in Purworejo Regency, including Dolalak Arum Sari, Dolalak Putri Mekar Indah from Baledono, Asri Budaya from Loano and others. Each group has special features, for example the dancer (prima donna), the variety of movements, the type of dance, or the form of presentation. While the accompanying tembang has similarities between one group and another, the difference is usually in "cengkok" and the tempo of the performance.

The bodily patterns that are often associated with elements of eroticism in the female Dolalak dance are very prominent in the aspect of the relationship between movement and dance clothing. In the female Dolalak dance, dance movements are presented visually such as in the male Dolalak dance. The most visible difference is that the male dance movements are danced by the female body. Of course, the female body will affect movement and the visual elements produced as a product of motion. The same reason also affects the body that is performed in the female Dolalak dance dress today. The Dolalak dance movement is a warrior movement dominated by clear and dynamic movements almost like a refined martial arts movement of pencak silat. The "kirig" movement, which is a fast shoulder movement at certain times, is the hallmark of the Dolalak Dance movement. Movement in this art is divided into four movements. Here are some of the basic movements of Dolalak Dance: - Foot movements: tiptoe, hit, pencik, lift leg, sempoh (bent legs), jengkeng. Hand movements: ngrayung / ngruji, taweng / tawing, 
ukel. - Neck movements: tolehan, pacak jonggo, and chocolate - Combined motion. It is a combined movement of the hands, feet, neck and body. Combined motion: pendulum (a combination of foot and hand movement), selut (continuous motion), siak, selut, kirig, lembehan, cakilan.

From this explanation, the change in presentation style is not only shown from the bodily role of female Dolalak dancers as well as the verbal message of song lyrics according to the body movements of the female Dolalak dancers. It is the most sensible indicator when the aesthetic visualisation of the choreographies of women's bodies impacts the movements produced on stage. This has turned out to be another consideration when verbal messages are also another indicator that has a role in producing choreographic visualisations of the body movements of female Dolalak dancers. In this case the collective and local forces occupy a separate position. This power is present in their tradition of terminology in the ideal form of women. This tradition is always written in traditional literary texts. One example that is later referred to from the ideal body type of Javanese women is widely published in Javanese traditional literature. In various Javanese literature, Javanese woman's physical ideal type is often called in various expressions. This ethnochoreologically becomes a humanistic understanding. The ethnocoreology position as a paradigm, also occupies a position as a perspective.

As a perspective it views the dance as not just a static representation of history, not just a repository of meaning, but a producer of meaning each time it is produced - not just a living mirror of a culture, but a shaping part of culture, a power within the culture (http://en.wikipedia.org/wiki/Ethnochoreology). Therefore it can be viewed as understanding humanity through the dance (https://educationireland.wordpress.com/.../ethnochoreologyunderstanding- humanity-through-dance-ul/). On that basis, the dancer's body aspect needs to be put forward as the main domain. At least from the female body segment of the Dolalak dancer, four body parts can be described which are divided from above; head, arms, torso, and legs. In Dolalak art, messages can be seen in dance movements (non-verbal) and through the accompanying songs (non-verbal). In the perspective of communication science, message is an important element. In the role of this female Dolalak dancer, the verbal domain goes together with the visual domain of the dance movement product. The feminine body of the female Dolalak dancer has transformed the dance into a new messenger. 


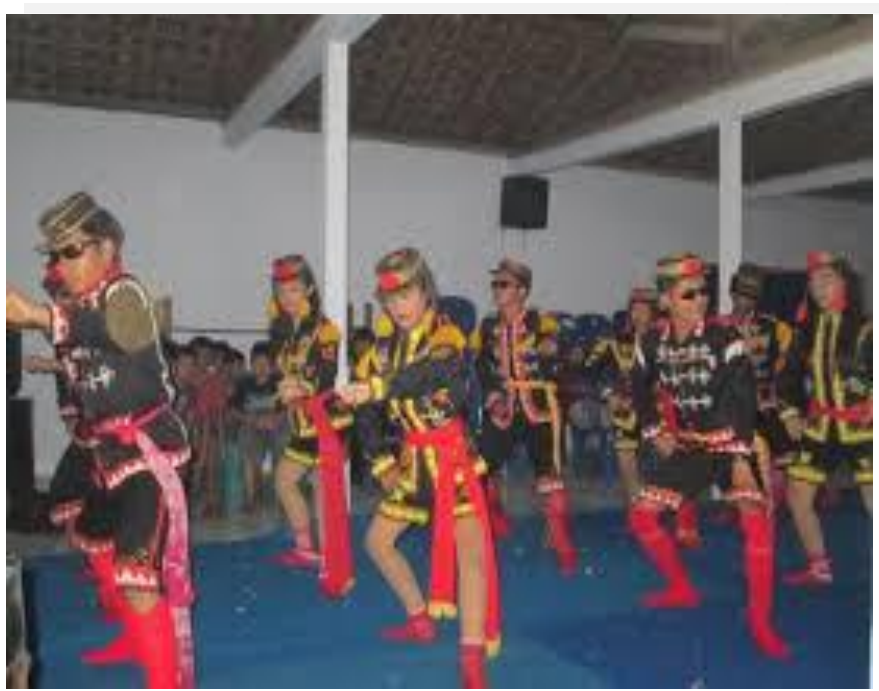

Figure 1. Siak dance position of upper leg gesture, arms and elbow on Dolalak Male (Photo by Pramutomo RM)

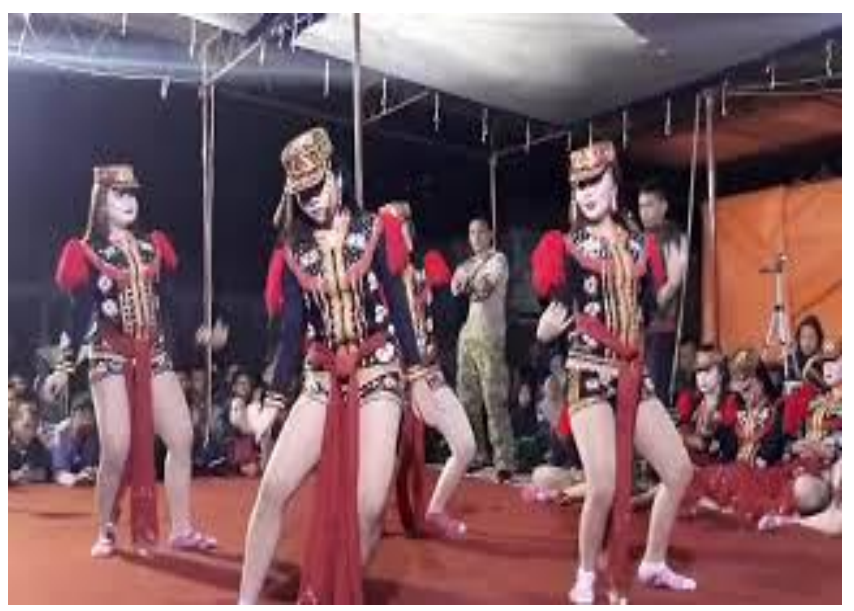

Figure 2. Siak position of full leg gesture, arms and elbow Dolalak Female (Photo by Pramutomo RM)

In the end, the difference between masculine and feminine leads to the assumption that masculine is attached to men who are manly, strong, brave, rational, dominant and active. Meanwhile, women's characteristics are identified with women who are weak, passive, submissive and emotional, and rely on physical attractiveness including beauty, sensuality and body curves (Kurnia, 2004: 20). The sensuality of a woman is an aspect that is often exploited by media actors to attract audiences. According to Ida and Surya (2002), this sensuality usually arises by attaching certain attributes to the woman, for example minimal and dreamy clothes. Its visual nature, can cause erotic arousal for the viewer. On that basis, in presentation or presentation style, female Dolalak is currently more erotic than male Dolalak, although the visualised form of movement is the same. Keywords in the area of performing arts act as processes of motion that contain certain technical qualities. This is why eroticism remains hidden because hidden eroticism is because the props are Javanese female Dolalak dancers. 


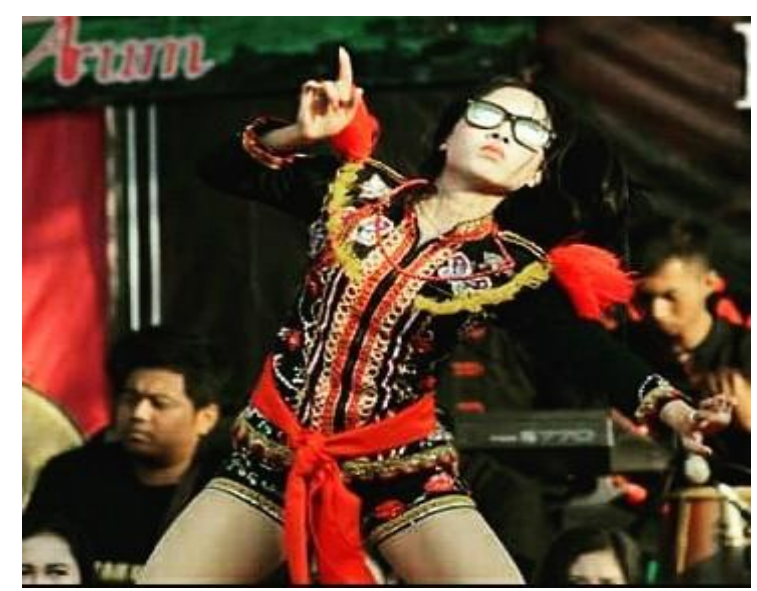

Figure 3. Female Dolalak Dancer in action trance (Photo by Pramutomo RM)

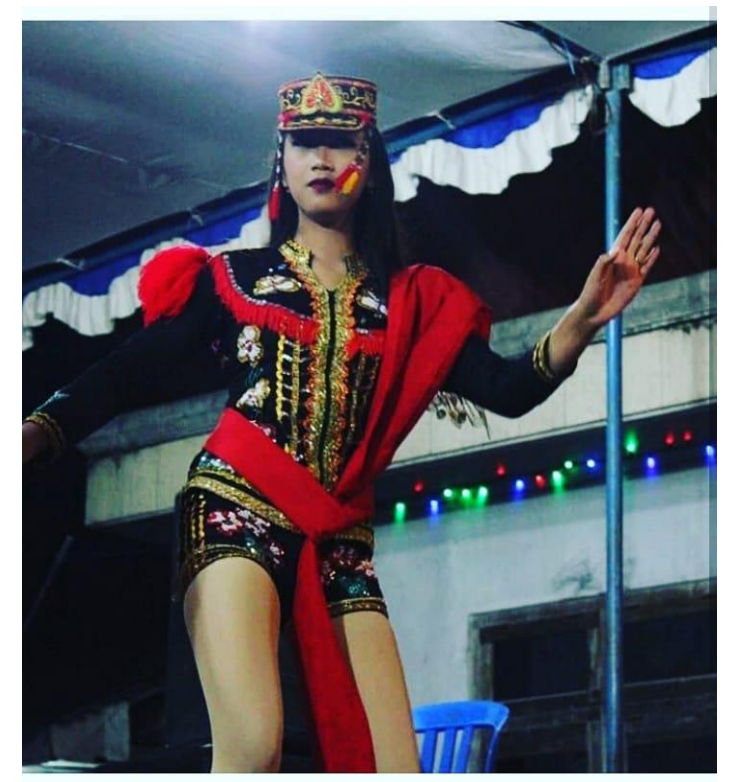

Figure 4. Female Dolalak Dancer seducing audience (Photo by Pramutomo RM)

Jung's view in the psychological analysis of the nature of anima in the female body is a separate reason. Joseph Campbell also highlighted Jung's theory of the phenomenon of a person's self related to the ego, the shadow and synergy which emphasised the nature of anima and animus. Apart from that, Jung also highlighted the difference in the concept of thought between an Eastern person and a Western person, which he called a difference in the cosmic perspective. He called the mind of the Eastern world a cosmic factor, which did not contrast the elements of science with religion. In the minds of the Western world, the conflict between science and religion is often seen as a mental factor. According to Campbell's analysis, the world of Javanese women introverts as Dolalak dancers cannot be ignored. Therefore the product resulting from a process of movement technically has the impression of being plastic and hidden, hidden eroticism. 
Comparable to Campbell's view, the sociological aspect of the female Dolalak dancer's body was emphasised by Foucault. Arivia follows Foucault's perspective said that women's bodies are considered as "other". This means that women's bodies are considered different from men's bodies. Women have certain body parts that are more prominent than men, such as breasts, hips and buttocks. This is what then makes women's bodies the target of exploitation. The parts of a female body that are considered different from this man are considered for selling. So it is not surprising that women's bodies are often used as visual objects by media actors, especially advertisers. In connection with a patriarchal society, the socio-cultural construction of women's bodies is used as a tool to maintain men's power and domination over women (Arivia, 2006: 95). This dominance can be seen from the power of the media, which places the female figure as the object of satisfying men's sexual desires.

This view is very useful when studying female Dolalak dancers that they never end up feeling victimised by media power. This is based on indicators of taste and pleasure factors obtained from use values in the form of a sense of flattery, and a sense of charm or self-image which is implemented in the visualisation of choreography and the process of hidden eroticism dance movements. Interestingly, an article has been written by Fajar Wijanarka in the Journal of Buana Gender, Volume 2 Number 2, 2017, by mentioning a special term of self-anatomy for Javanese women (Wijanarka; 2017; 1311--132). It is also often traditionally thought that Javanese women contain the expression drijine mucuk eri, which speaks of the slits of a woman's fingers, lengene gandhewa pinenthang, which describes the beauty of women's arms, lembehane blarak sempal, which depicts the swing of the arms when women walk. Bangkekane nawon kemit depicting beautiful hips of women, and so on. This common expression that still appears frequently is an anatomical image of the self that is inherent in the physical beauty of Javanese women. If this is implemented in an entertainment pattern, it may result in a new form of communication in the body language of female Dolalak dancers.

\section{Conclusion}

Dolalak as an art with a da'wah message has increased its role in bringing entertainment messages. Since its prototype was created in Mlaranan Village, Dolalak women's dance has transformed into an entertainment movement in Purworejo Regency. The presence of the female Dolalak dance is the ability to enchant the audience not only to request the song to be sung. But more than that, it is able to form new social relationships with social media filled with photos, videos, and reviews and comments aimed at a number of women's Dolalak dance groups.

This pattern is a new form of movement when changes in the appearance of women's Dolalak are able to replace other entertainment arts. The fact of appearance in the demonstration of certain movement motives is also another proof when the way to move women's body parts is sexier than men's bodies. Although that fact is actually the exact same motion. We hope that 
the anatomy of women is more flexible in presenting Dolalak dance. Body communication that is expressed also often gets a response from the general audience. This then resulted in a trend of change to not only entertain, but also to value the eroticism hidden behind bodily communication. In the end, this article comes to the opinion that female Dolalak dancers are more communicative than male Dolalak dancers. The pattern of body communication expressed in the dancer's language often results in the hidden erotic movement among female Dolalak dancers. 
International Journal of Innovation, Creativity and Change. www.ijicc.net

Volume 15, Issue 8, 2021

\section{REFERENCES}

Arivia, Gadis, Christina Siwi Handayani et.al; Subyek Yang Dikekang: Pengantar ke Pemikiran Julia Kristeva, Simone de Beauvoir, Michael Foucault, Jaques Lacan. Jakarta: Komunitas Salihara 2013.

Campbell, Joseph, ed., The Portable Jung,. Terj. R.F.C. Hull, (New York, Middlesex, Victoria, Ontario: Penguin Books Ltd., 1971.

Geertz, Cifford, The Interpretation of Culture (New York: Basic Books Publishers, 1973.

"Globalisasi, Diplomasi Kebudayaan dan Komodifikasi Budaya"

(http://staff.undip.ac.id/sastra/mahendra/ 2009/07/23),

Hawkins, Alma M., Creating Through Dance, New York: Basic Book Publishers, 1988.

Horton-Freleigh dan Heinstein eds. Researching Dance: Evolving Modes of Inquiry. Pittsburgh University Press 1999.

http://en.wikipedia.org/wiki/Ethnochoreology

https://educationireland.wordpress.com/.../ethnochoreology-understanding- $\quad$ humanitythrough- dance-ul/

Morris, Desmond, People Watching: A Field Guide to Human Behaviors. New York: Harry N Abrahms, 2000.

Olsen, Marvin E The Process of Social Organization (New Delhi, Bombay, Calcutta: Oxford and IBH Publishing, Co, 1975).

Prihatini, Nanik Sri, Bentuk Pertunjukan Tari Dolalak Purworejo. Surakarta: ISI Press Solo 2003.

Salimah,"Peran Tari Dolalak Dalam Penyebaran Agama Islamdi Desa Kaliharjo, Kecamatan Kaligesing, Kabupaten Purworejo (1936-2007"

Santosa, Djarot Heru , Timbul Haryana dan R.M. Soedarsono berjudul "Seni Dolalak Purworejo Jawa Tengah: Peran Perempuan Dan Pengaruh Islam Dalam Seni Pertunjukan

“ dalam Jurnal Kawistara, Volume 3 No. 3, 22 Desember 2013

Santosa. Komunikasi Seni. Surakarta: ISI Press Solo, 2011.

Supantho, Memperkenalkan Tari Dolalak, Pemerintah Kabupaten Purworejo, 1997.

Sutrisno, Isbandi J "Perubahan Orientasi pada Pesan Verbal Tembang dalam Seni Tradisional Angguk dan Dolalak" Jurnal Ilmu Komunikasi, UPN VeteranYogyakarta

Volume 8, Nomor 3, September - Desember 2010, halaman 330 - 343.

Th. Pigeaud, Javaansche Volksvertoningen, Batavia Nijhoff, 1935

Wijanarka , Fajar, " Gender dan Domestikasi Perempuan (Pendekatan Kodikologi Visual Naskah Dewi Mutasiyah)Dalam Jurnal Buana Gender - Vol. 2, Nomor 2, Juli Desember 2017 , 131--132. 